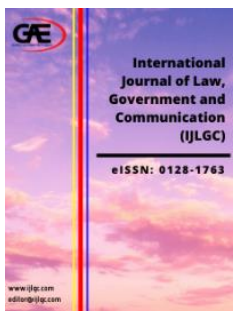

\author{
INTERNATIONAL JOURNAL OF LAW, \\ GOVERNMENT AND COMMUNICATION \\ (IJLGC) \\ www.ijlgc.com
}

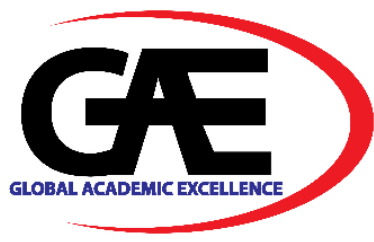

\title{
ILLEGAL MEDICAL PRODUCT AND CONSUMER PROTECTION IN MALAYSIA
}

\author{
Zeti Zuryani Mohd Zakuan ${ }^{1 *}$, Rahmah Ismail ${ }^{2}$ \\ 1 Department of Law, Universiti Teknologi MARA, Cawangan Perlis, Malaysia \\ Email: zeti@uitm.edu.my \\ 2 Fakulti Undang-undang, Universiti Kebangsaan Malaysia, Malaysia \\ Email: irahmah@ukm.edu.my \\ * Corresponding Author
}

\section{Article Info:}

Article history:

Received date: 17.06 .2021

Revised date: 30.06 .2019

Accepted date: 15.07.2021

Published date: 01.09.2021

\section{To cite this document:}

Zakuan, Z. Z. M., \& Ismail. R. (2021). Illegal Medical Product and Consumer Protection in Malaysia. International Journal of Law, Government and Communication, 6 (25), 01-08.

DOI: $10.35631 /$ IJLGC.625001

This work is licensed under CC BY 4.0 (c) (2)

\begin{abstract}
:
The demand for medical products increases dramatically due to the outbreak of the COVID-19 pandemic. In this instance, unscrupulous traders are seen to be taking advantage of the situation by selling illegal medical products. These illegal products can be toxic and pose a severe health risk to consumers, as they may include the wrong ingredients, ineffective ingredients, or no active ingredients. One of the factors identified in the increase in the sale of illegal medical products is the ineffectiveness of the existing law to act as a deterrent. Growth in the activity is because the profits gained from selling the products are much higher than the fine imposed. By adopting doctrinal research and using content analysis methods, the article aims to identify the protection conferred to consumers concerning illegal medical products under the existing law. The article further examined the liability imposed on the manufacturer for a defective product which resulted in consumer suffers injury. It is submitted that the primary legislation, which is the Consumer Protection Act 1999, is ineffective in protecting consumers concerning illegal medical products. Thus, reference is made to the German Medicinal Product Act, which provides for liability of the manufacturer for the medicinal products.
\end{abstract}

Keywords:

Illegal Medical Product, Consumer Protection, Product Liability, Consumer Protection Act 1999

\section{Introduction}

The outbreak of COVID-19 pandemic has seen an increase in the production of medical products as part of the efforts to tackle the virus. Among medical products detected are test kits, personal protective equipment, chemical-based products, ventilators, medicines, blood 


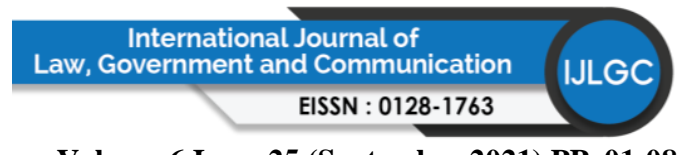

Volume 6 Issue 25 (September 2021) PP. 01-08

DOI 10.35631/IJLGC.625001

products, and vaccines (Fairgrieve et al., 2020). The increase in the production of medical products contributes to the sale of illegal products in Malaysia. Interpol supervised Operation Pangea XIII, which is an international operation was conducted in Malaysia to fight the distribution and sale of illegal pharmaceuticals and medical products. In a week of the operation, illegal products worth $\$ 14$ million have been seized worldwide (Ong, 2020). In Malaysia, the Ministry of Health had seized more than one million unregistered medicines worth RM 2.55 million. The Ministry also seized 23278 illegal pharmaceutical products worth more than RM 600,000 during raids on 50 unlicensed premises (Khairulrijal, 2021). The statistics show the seriousness of illegal medical products in the Malaysian market. These illegal products can be toxic and pose a severe health risk to consumers, as they may include wrong ingredients, ineffective ingredients, or no active ingredients. Thus, the government needs to protect the consumers so that they will not become the victim of unscrupulous traders.

\section{Methodology}

The study was conducted using qualitative approach. The study uses content analysis method which employs analytical and critical approach. The approach is vital for this study since written materials from library search and internet will be thoroughly analysed. This approach has been used in order to gain an insight into the situation of illegal medical product and consumer protection in Malaysia. The study also adopted comparative approach. Comparative approach enables the authors to highlight the benefits and shortcomings of the existing consumer legislation in Malaysia. Comparison is made to German Medicinal Product Act. According to Cruz (1999), comparison between two legal systems is important in order to come out with a new model which is more comprehensive. This view is supported by Yntema (1956). He felt that comparative approach will improve and expand the knowledge regarding the chosen field of study.

\section{Malaysian Consumer Protection}

In Malaysia and all around the world, all consumers are granted with eight basic rights which includes right to healthcare. The government is under an obligation to ensure that these rights are granted to the consumers. Consumers are said to be deprived of their right to healthcare if, for example, the product they purchased and consumed is harmful to their health. Thus, the government needs to do something to overcome this problem. The Consumer Protection Act of 1999 (CPA 1999) is a legal framework established by the Malaysian government to safeguard the consumers. The Malaysian government recognised the need for consumer protection and established eight consumer-oriented ministries for this reason. Ministry of Domestic Trade and Consumer Affairs, Ministry of Agriculture and Food Industries, Ministry of Finance Ministry of Health, Ministry of Transportation, Ministry of Housing and Local Government, Ministry of Human Resources and Ministry of Science, Technology and Innovation are among the ministries introduced (Zakuan et al., 2014).

Definition of consumer is provided under section 3(1) CPA 1999 as "a person who acquires or uses goods or services of a kind ordinarily acquired for personal, domestic or household purpose, use or consumption." The definition illustrates that a consumer is a person who purchases goods or services solely for domestic or household consumption. They might be someone who is lack of experience and not well equipped with scientific and technology knowledge. As opposed to manufacturers, the consumer is also someone who has no bargaining power. Due to the situation of unequal bargaining power, the manufacturers tend to take 


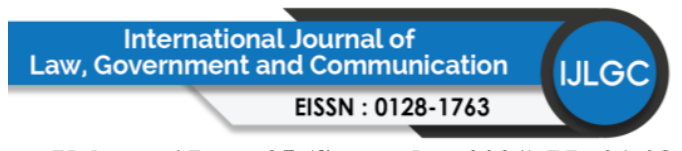

Volume 6 Issue 25 (September 2021) PP. 01-08

DOI 10.35631/IJLGC.625001

advantage of the consumers. As a result, consumers must be safeguarded against the manufacturers. The issues on many aspects of consumerism in Malaysia demonstrate the necessity of consumer protection. For this purpose, a specific Ministry which is known as the Ministry of Domestic Trade and Consumer Affairs has been introduced to cater for consumer matters. The government also had introduced the Malaysian Plan, which outlined the protection given to the consumers. The Consumer Protection Act 1999, which focuses on consumer interests, is enacted as part of the 7th Malaysian Plan. This legal framework is necessary to safeguard consumers and to control society.

\section{Illegal Medical Product}

Illegal medical products have become an acute problem for consumers in Malaysia. The problem is expanding due to the large number of medical products used by consumers in Malaysia. The Ministry of Health $(\mathrm{MoH})$ is in charge of the issues relating to medical products. The Pharmacists Registration Act 1951, Poisons Act 1952 (Revised 1989), Sale of Drugs Act 1952, Food Act 1983, Medicines (Advertisement and Sale) Act 1956 (Revised 1983) and Disease Prevention and Control Act 1988 were all enacted by the Ministry to protect Malaysian consumers in relation to medical and pharmaceutical issues. The enactment of these Acts shows the seriousness of $\mathrm{MoH}$ in tackling issues relating to medical products in Malaysia. Despite the enactment of the Acts, the MoH has established special divisions to handle medical and pharmaceutical products and services. The divisions introduced are National Pharmaceutical Regulatory Agency (NPRA), Pharmacy Enforcement Division (PED) and Pharmacy Practice and Development Division (PPDD).

The function of the Pharmacy Enforcement Division can be seen in a study conducted by Loo et al. (2019). The study aims to assess the rate of prosecution and the severity of fines and prosecutions for unregistered cosmetics and drugs, in which illegal medical products are among them. It was found that the highest penalty recorded in the year 2016 was a fine or RM 20000, which is very low as compared to the damage done to the consumers. Offences prosecuted are under Poison Act 1952 and Control of Drugs and Cosmetic Regulations 1984. The maximum penalty for any offences under the Act is RM 2000 for an individual and RM 50000 for a company. The study shows that the median fine imposed for offences was committed under Poison Act 1952 and Control of Drugs and Cosmetic 1984, raging between RM850 to Rm3000 for 2014 to 2016. They concluded that the penalties imposed do not address the underlying public health impact of the illegal drug. They further opined that light penalties imposed, contributed to the increase of illegal medical and drug industries in Malaysia.

Under Malaysian law, there is no exact definition for illegal medical product. Nonetheless, Regulations 7 Control of Drugs and Cosmetics Regulation 1984 contain explicit rules require all medical products to be registered with the National Pharmaceutical Regulatory Agency (NPRA) prior to being placed on the market. It must also follow a procedure that includes a thorough review and final clearance by the Drug Control Authorities (DCA). Once the medical products have undergone all the processes, the products are then considered as registered products. In Malaysia, the term "registered drugs" or "registered products" refers to medical items that have met all of the standards (Zulkifli et al., 2016). From this provision, it is presumed that illegal medical product falls under the definition of unregistered drugs. Thus, it is observed that the existing law does govern illegal medical products. 


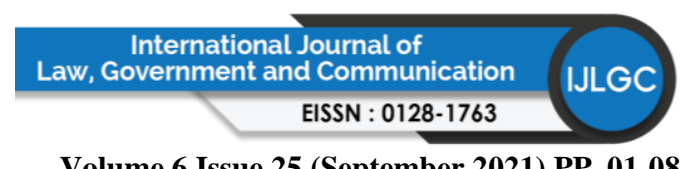

Volume 6 Issue 25 (September 2021) PP. 01-08

DOI 10.35631/IJLGC.625001

The issue with illegal medical products on the market is that they are often of poor quality and can be hazardous (Mazlan, 2013). Consumption of the products may have a negative impact on the consumers' health (Bidin, 2009). As a result, the government should prohibit certain products from being sold. The question then becomes whether consumers are protected if the illegal medical product they consume is defective and they are injured because of the defect. In this situation, product liability becomes extremely important.

\section{Product Liability Law in Malaysia}

Product liability refers to the obligation to compensate a person for damage caused by a product (Ringstedt, 1995). Product liability law in Malaysia is introduced in Part X of the CPA 1999. The law adopts the strict liability concept for the first time in Malaysia. Part X is based on the UK Consumer Protection Act 1987, which incorporates the European Product Liability Directives (85/374/EEC). The strict liability regime introduced in Part $X$ holds the manufacturer liable for any injury suffer by a consumer as a result of product which is found defective. Strict liability abolished the need to prove a breach of contract or breach of duty, which was the practice pre-1999 (Ismail et al.,2015). Part X established a strict liability framework in cases which involves death, injury, or loss of personal property as a result of defective products. Thus, Part X of the CPA 1999 can be used by a consumer who has been injured by an illegal medical product.

The law governing product liability in Malaysia is provided under section 68 (1) of the Consumer Protection Act of 1999. Section 68 (1) establishes a strict liability regime under which the producer, manufacturer, and importer are all accountable for damage caused entirely or partially by a defect in a product. According to Part X of the CPA 1999, in order to succeed in a claim against the manufacturer, the consumer must prove three essential elements namely, defect, damage, and the relationship of defect and damage. To date, law relating to product liability has not been challenged. Thus, the law's effectiveness is still questionable.

\section{Defect}

In product liability claims, a defect is the first essential element that the consumer must prove. According to Rheingold (1970), a defect is something that contributes to injury. A defect is said to exist according to section 67 (1) CPA 1999 if the product's safety falls short of what a reasonable person might expect. In establishing a defect, the burden of proof is vested upon the consumer to prove the defect (Keeton, 1980). "Consumer expectation test" is used to determine defects in accordance with this section.

Some English cases demonstrate the problems in the implementation of the "consumer expectation test". Since Malaysian CPA 1999 has not been challenged, English cases can be relied upon to examine the problem of "consumer expectation test" A and others v National Blood Authority and Others [2002] 3 All ER 289 is one example to illustrate this problem. In this case, blood transferred to the plaintiff was identified to be tainted with hepatitis C. Plaintiff claimed that the blood transferred should be free from contamination. The court found that the blood is defective because it was contaminated during the transfusion. Burton $\mathbf{J}$ stated that the application of "consumer expectations test" is not to be allowed. He argued that the law should not expect the consumer to apply the test since the consumer is not aware of the market's standard of goods. According to him, this job needs to be left to the judiciary as the judicial community is labelled as "the reflector of community standard." 


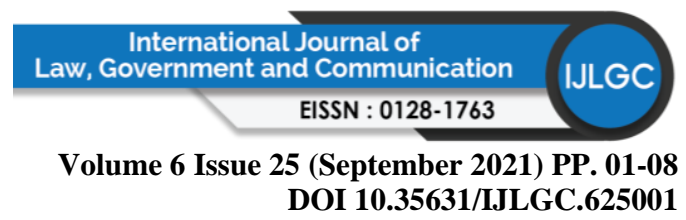

\section{Damage}

Damage is the second element that the consumer must prove in a product liability claim. Damage can be injury, harm, illness that the plaintiff suffers due to the defect in the product. It is vital for the consumer to prove that damage exist due to the defect of the product. According to section 66 CPA 1999, a consumer can bring an action for product liability for death, personal injury and damage to private property. Literally, consumers might not have a problem proving damage.

\section{Causal Relationship of Defect and Damage}

The third element that the consumer must prove in a product liability claim is the causal relationship of the defect and the damage. Consumer must prove that the damage or injury occurs as a result of the product which is defective. However, it is a challenge for the consumer to prove this. Consumers with a low level of knowledge might have difficulties proving that damage occurs due to defective products. The law should not expect the consumer to know about the goods that they consumed. Hodges (1999) argued the burden of proving this causality is troublesome to the consumer. He commented that consumers normally do not have the capability either financially or technically to establish a defect, mainly in highly complicated products like chemical or pharmaceutical products. The problem can best be illustrated by the case of Foster v. Biosil (2001) 59 BMLR 178. The case involved an artificial breast implant. The plaintiff is in pain as a result of leaking in the artificial breast. It was decided that there was no causal relationship, although the plaintiff had suffered pain due to the leakage. This case addressed the problem of a relationship of defect and damage. It is suggested that the court should interpret the relationship less strictly. The application of strict liability requires the consumer to prove the relationship. The practice is unfair to the consumer because the consumer is vulnerable. They are not aware of the production process, especially when it involves a technically complex product (Zakuan, 2019). Fairgrieve et al., (2020) opined the EU Product Liability Directive (which is adopted in our local product liability law) is also unable to solve the issue of medical products. According to Mokhtar (2013), CPA, 1999 fails to respond to consumers' need to obtain compensation against the manufacturer.

Apart from the burden of proof, Part X of CPA 1999 also provides defences for the manufacturer. Section 72 (1) CPA 1999 provides five defences that the manufacturer can rely on. If the manufacturer can prove the defences, then the manufacturer can escape liability. The most prominent defence is the "state-of-the-art defense" provided under section 72(1)(d). According to Section 72(1)(d), the manufacturer has a defense if when the product is under his control, other manufacturer of similar product also could not find the defect in their product based on the knowledge of scientific and technology at that particular time. The manufacturer must show that no other suppliers or manufacturers of identical products can discover the defect in their product. Graham Barclay Oyster Pty v Ryan 102 FCR 307 is a good example to illustrates the defense. Ryan contracted Hepatitis A after eating oysters grown by the manufacturer. Lindgren $\mathrm{J}$ decided that, at that time, knowledge of science and technology could not discover the defect unless extensive checking was conducted on the oysters. This behaviour, on the other hand, would result in the oysters' destruction. As a result, the producer was be able to rely on "state-of-the-art defense" and can easily escape liability. 


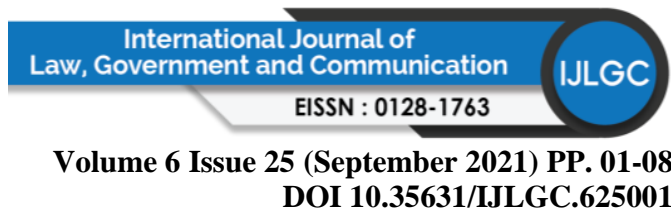

Claims made by the consumer under Part X of the CPA 1999 are hindered by the defenses offered under section 72(1) of the CPA 1999. The existence of defences provides the manufacturer with the opportunity to avoid liability. If the manufacturer can prove the defences, the claim made by consumers would be denied. Section 72(1)(d) is the most prominent defence under Part X. In cases involving defective medical products during the pandemic. The manufacturer can definitely avoid liability by depending on section 72(1) (d). During the pandemic, the manufacturers are competing to produce medical products in a large scale. As a result, they omit the duty to ensure safety of the products. In this situation, the manufacturer can easily escape liability because other manufacturers also might not have discovered the defect. The unscrupulous manufacturer will take advantage of the situations and involves in the mass production of medical products without worrying about the product's safety, efficacy, and efficiency. As a result, the consumers will suffer damage due to the defect. The manufacturer would most likely succeed to prove this defense since it is based on the manufacturer's knowledge rather than scientific and technology knowledge.

The above discussion illustrates that the existing law on product liability is ineffective to protect the consumers in relation to defective product. Thus, it is apparent that the current legal framework is incapable of safeguarding injured customers due to the consumption of illegal medical products. As a result, something needs to be done to prevent this from happening. The best way would be to punish the manufacturer for harm and injury suffered by the consumer of illegal medical products.

\section{German Medicinal Products Act (Arzneimittelgesetz - AMG)}

In German, medical product is governed by Medicinal Products Act (Arzneimittelgesetz AMG). The Act was published on 12 December 2005. It consists of 18 chapters and 147 sections. The Act aims to ensure the adequate supply of medicinal products as well as trade safety. Furthermore, it is to ensure that medicinal products are of high quality, efficacy, and safety.

Liability for damage caused by medicinal products is addressed in Chapter 16 . The chapter provides absolute liability towards the manufacturer of medical products, which covers section 84 until section 94 . The liability of the manufacturer is clearly explained in section 84 . It provides that if a consumer is killed or the health is substantially damaged due to consumption of the medicinal product, the manufacturer should be obliged to compensate the injured party for the damage. In the case of death, the extent of liability for damages is determined by Chapter 86 , whereas in the case of bodily injury, the liability for damages is determined by Section 87. Basically, according to both sections, the manufacturer shall make good the loss suffered by the victim as well as their dependent. The above discussion illustrates that the German Medicinal Product Act (Arzneimittelgesetz - AMG) does provide for consumer protection relating to medicinal products in Germany. Undoubtedly worldwide pharmaceutical companies attempt to make money by rushing medical products into the market. However, it is vital for relevant law relating to medical product to be in place to protect the consumer around the world.

\section{Conclusion}

In Malaysia, law relating to product liability is governed by Part X of CPA1999. On the surface, product liability appears to be capable of providing remedies in the event of injury to the consumer in cases involving defective product. The obligation is placed on the consumer to 


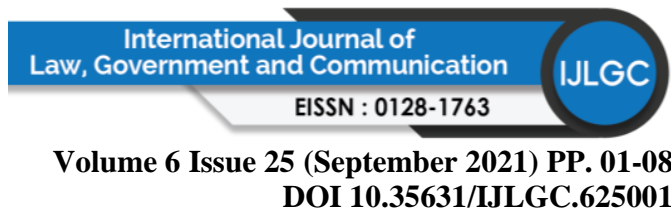

prove the defect, which is unfair to the consumer. They are a susceptible category of persons who are unaware of the manufacturing process, particularly when a technically complicated product is involved. Aside from that, the manufacturer's defences, particularly the state-of-theart defense, will make it difficult for consumers to succeed in their claims. Recognizing this issue, it is argued that the Consumer Protection Act of 1999 (CPA 1999) is ineffective in protecting consumers from illegal medical products. Malaysia may need to learn lessons from other jurisdictions and consider amending the existing law on product liability relating to medical products. The government should consider best practices from Germany, that has enacted specific law for medicinal product to assist in consumer claims.

\section{References}

Bidin, A. (2009). Counterfeit Medicine: A threat to the public health and pharmaceutical industry. In International Conference on Corporate Law, Malaysia UD.

Cruz, P. D. (1999). Comparative law in a changing world. London: Cavendish Publishing Limited.

Fairgrieve, D., Feldschreiber, P., Howells, G. \& Pilgerstorfer, M. (2020). Products in a pandemic: Liability for medical products and the fight against COVID-19. European Journal of Risk Regulation,11(3),565-603.

Hodges, C.J. (1999). Reform of the Product Liability Directive 1998-1999. Consumer Law Journal, 7,35-48.

Ismail, R., Zakuan, Z.Z.M., Yusoff, S.S.A, Markom, R., Mohamed Isa, S. \& Abdul Aziz, A. (2015). Product liability law under the Malaysian Consumer Protection Act 1999: Justice for consumers, International Business Management, 9(6),1290-1296.

Keeton, W.P. (1980). The meaning of defect in products liability law-A review of basic principles. Modern Law Review, 45, 579.

Khairulrijal, R. (2020). Covid - 19: Sales of illegal medicines soar, Operation Pangea XIII, https://www.nst.com.my/news/nation/2020/04/588631/covid-19-sales-illegalmedicines-soar (2020, accessed 12 April 2021).

Loo, S.C., Norkhair, M.I., Hsiung, T.M., Jabar, A.H.A.A. \& Talin, B.A.A. (2019). Overview of prosecution against illegal drugs and cosmetics by pharmacy enforcement branch (PEB) in Sarawak Malaysia. International Journal of Research in Pharmaceutical Sciences, 10 (SPL1).

Mazlan, I. (2013). Counterfeit medicinal products: The challenges nowadays towards NCD (Malaysia Experience). Pharmaceutical Services Ministry of Health Malaysia.

Mokhtar, F.S., Ismail, R. (2013). Medical Product liability under the Consumer Protection Act 1999. The Social Sciences, 8(6), 565-73.

Ong, C., Yee K P, \& Shuh G. Y. (2020). Fake goods epidemic during the Covid 19 global pandemic. https://www.skrine.com/insights/newsletter/july-2020/fake-goodsepidemic-during-the covid-19-global-pandemic (2020, accessed 10 April 2021).

Rheingold, P.D. (1970). Proof of defect in product liability cases. Tennesse Law Review, 38, 325.

Ringstedt, N. (1995). The practical application of Council Directives Relating to Product Liability and Product Safety in a consumer safety context, Ritsumeikan Law Review, 11, 217-26.

Yntema. (1956). Comparative legal research: Some remarks on 'looking out of the cave' 54 Michigan Law Review, 899, 901-903. 
Volume 6 Issue 25 (September 2021) PP. 01-08

DOI 10.35631/IJLGC.625001

Zakuan, Z.Z, Ismail, R. (2019). Health Supplement and Product Liability in Malaysia: A Call for Reform, Malaysian Journal of Consumer and Family Economics, 23(1), 33-55.

Zakuan, Z.Z.M., Yusoff, S.S.A., Ismail, R. \& Markom, R. (2014). Health Institution as a Consumer Protection Framework in Malaysia. Global Journal of Politics and Law, 2(3), 77-83.

Zulkifli, N.W., Aziz, N.A., Hassan, Y., Hassali, M.A., Bahrin, N.L., Ahmad, A. (2016). Are we on the right track?: Overview of unregistered drugs in Malaysia. J Pharm Pract Community Med, 2(4), 107. 